\title{
Abnormal Growth in Noonan Syndrome: Genetic and Endocrine Features and Optimal Treatment
}

\author{
Raja Padidela $^{\mathrm{a}}$ Cecilia Camacho-Hübner ${ }^{\mathrm{b}}$ Kenneth M. Attie ${ }^{\mathrm{c}}$ \\ Martin O. Savage ${ }^{\text {a }}$ \\ a Department of Endocrinology, Barts and London School of Medicine and Dentistry, London, UK;

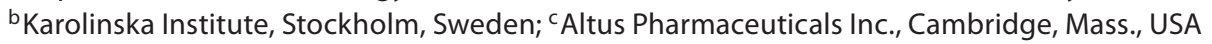

\section{Key Words}

Noonan syndrome $\cdot$ Growth $\cdot$ Genetic defects $\cdot$ Growth

hormone therapy

\begin{abstract}
Noonan syndrome (NS) is a phenotypically heterogeneous syndrome which is frequently associated with short stature. Recent genetic investigations have identified mutations in five genes, namely PTPN11, KRAS, SOS1, NF1 and RAF1 in patients with the NS phenotype. PTPN11 is the commonest, being present in approximately $50 \%$ of cases. The degree of short stature in children does not associate closely with the presence of mutations, however some PTPN11-positive patients have decreased $\mathrm{GH}$-dependent growth factors consistent with mild GH insensitivity. GH therapy, using doses similar to those approved for Turner syndrome (TS), induced short-term increases in height velocity over 1-3 years, and may improve final adult height with longer-term treatment.

Copyright $\odot 2008$ S. Karger AG, Base
\end{abstract}

\section{Introduction}

Noonan syndrome (NS; OMIM163950) is a developmental dysmorphic syndrome characterized by clinical and genetic heterogeneity. In 1930, Ullrich [1] described several male and female patients with short stature and webbed neck, and for a while the syndrome was known as Ullrich-Bonnevie phenotype. However, the definitive phenotype was described by Dr Jacqueline Noonan, a pediatric cardiologist, reporting patients with cardiac valvular stenosis, distinct dysmorphic facialfeatures, webbed neck and chest deformities [2]. Short stature is a recognized feature of NS and its natural history from birth to adulthood was first described by Witt et al. [3].

\section{Clinical Features}

NS in childhood presents with wide phenotypic heterogeneity. Clinical features may vary between affected members of the same family and also change with age becoming more mild in adult life [4]. The clinical features may be so subtle that some patients without a known heart defect are considered to be normal during childhood. The characteristic facial features are hypertelorism, down-slanting, anti-mongoloid, palpebral fissures, ptosis, and low-set posteriorly rotated ears with a thickened

Prof M.O. Savage

Department of Endocrinology, John Vane Science Centre

Charterhouse Square

London EC1M 6BQ (UK)

Tel. +44 207882 6233, Fax +44 207882 6234, E-Mail m.o.savage@qmul.ac.uk 
Table 1. Molecular genetic findings in Noonan syndrome

\begin{tabular}{|c|c|c|c|c|c|c|}
\hline Mutation & First identified by & $\begin{array}{l}\text { Chromosome } \\
\text { loci }\end{array}$ & Mutation rate & Protein affected & $\begin{array}{l}\text { Pathway } \\
\text { involved }\end{array}$ & Testing method \\
\hline PTPN11 & Tartalgia et al. 2001 [22] & $12 \mathrm{q} 24.1$ & $40-50 \%$ & $\begin{array}{l}\text { Non-receptor } \\
\text { tyrosine } \\
\text { kinase SHP-2 }\end{array}$ & RAS-MAPK & Sequence analysis \\
\hline KRAS & Schubbert et al. 2006 [25] & $12 \mathrm{p} 12.1$ & $3 \%$ & GTPase KRAS & RAS-MAPK & Sequence analysis \\
\hline SOS1 & $\begin{array}{l}\text { Tartaglia et al. } 2007 \text { [27] } \\
\text { Roberts et al. } 2007 \text { [26] }\end{array}$ & $2 \mathrm{p} 22-\mathrm{p} 21$ & $10 \%$ & SOS1 & RAS-MAPK & Sequence analysis \\
\hline NF1 & Hüffmeier et al. 2006 [30] & $17 q 11.2$ & $\begin{array}{l}100 \% \text { in phenotypic } \\
\text { overlap subject }\end{array}$ & Neurofibromin & RAS & Sequence analysis \\
\hline RAF1 & $\begin{array}{l}\text { Pandit et al. } 2007 \text { [31] } \\
\text { Razzaque et al. } 2007 \text { [32] }\end{array}$ & $3 \mathrm{p} 25.2$ & $3 \%$ & MEK1, MEK2 & RAS-MAPK & Sequence analysis \\
\hline
\end{tabular}

helix. Pulmonary stenosis (50-62\%) and hypertrophic cardiomyopathy (10-20\%) are the most frequent heart defects. Feeding difficulties, bleeding diathesis (20\%) and lymphatic dysplasias are also reported [5]. Other characteristics may include mild mental retardation, cryptorchidism, clotting disorders, hypogonadism, autoimmune thyroiditis, thoracic deformities, hearing difficulty, and juvenile myelomonocytic leukemia. Scoring systems based on phenotypic characteristics were devised to improve diagnostic sensitivity and specificity $[6,7]$ and have resulted in a higher percentage of genotype positivity [8].

\section{Growth}

Prenatal linear growth was initially reported to be normal [9], although edema may influence birth weight [10]. More recently, French and Japanese studies have reported mean birth weight and length SDS between 0 and -2 for the relevant populations [11, 12]. During childhood, mean height in both sexes approximates the third percentile until approximately 12 years in males and 10 years in females, after which mean height decreases below the normal range due to delayed puberty and decreased pubertal growth spurt [9]. Adult height has been reported by several groups [9]. Noonan et al. [13] described adult heights in 73 subjects aged over 21 years and reported $30 \%$ of males and females had heights above the 10 th centile and $38 \%$ of males and $54.5 \%$ of females had heights below the 3 rd centile. More recent British data reported mean adult height to be $167.4 \mathrm{~cm}$ in males $(\mathrm{n}=$ $18)$ and $152.7 \mathrm{~cm}$ in females $(\mathrm{n}=25)$ [14]. Overall, mean adult height is approximately $-2 \mathrm{SD}$.

\section{Genetic Features (table 1)}

The incidence of NS is unknown, but is suggested to be in the region of $1: 1,000$ to $1: 2,500$ [15]. The syndrome may be familial, being inherited more commonly as an autosomal dominant [16] rather than a recessive [17] disorder; at least $50 \%$ of cases appear to be sporadic $[4,5]$. Progress in the identification of a genetic cause of the syndrome came from the demonstration, from a genomewide linkage analysis of a large Dutch kindred with autosomal dominant NS, of a probable gene locus on chromosome 12q [18]. Analysis of a four-generation Bulgarian family and a three-generation Dutch family further delineated and refined the critical locus to the N-SH2 component on chromosome 12q24.1 [19, 20]. Chen et al. [21], working in a mouse mutant model, independently reported genetic interaction between the epidermal growth factor receptor (EGFR) and protein tyrosine phosphatase, nonreceptor type 11 (PTPN11), which encodes a ubiquitously expressed cytoplasmic protein containing two Src homology 2 domains, SHP-2. EGFR was required for semilunar valve development [21]. In 2001, Tartaglia et al. [22] reported that missense mutations in the PTPN11 gene caused NS. The same group reported PTPN11 mutations in 59\% of individuals with familial NS and $37 \%$ of sporadic cases $(p<0.02)$, suggesting that unidentified genes also contributed to NS and phenotypically related disorders such as LEOPARD, cardio-facial-cutaneous and Costello syndromes [23, 24].

Most PTPN-11 mutations in NS were missense involving a single amino acid in exons 3,7 , or 8 of the gene. $\mathrm{Mu}-$ tations involved either the N-SH2 or PTP domain leading to gain in function of the SHP-2 protein inducing increased phosphatase activity. It is not known with preci- 
sion how expression of mutant SHP-2 translates into the specific NS phenotype [24]. SHP-2 plays a positive regulatory role in signal transmission via the receptor tyrosine kinase (RTK)-mediated RAS/ERK pathway. Through downstream signal transfer, SHP-2 phosphatase relays signals from activated RTK to effectors of the K-RAS protein leading to RAS-ERK cascade activation.

Twenty-five percent of cases of juvenile myelomonocytic leukemia (JMML) demonstrate a mutation in the KRAS or NRAS gene. Using sequence analyses, Schubbert et al. [25] found a KRAS gene mutation in a PTPN11negative female infant with the severe NS phenotype and associated JMML. Subsequent analyses of 174 NS subjects negative for a PTPN11 mutation and not suffering from JMML revealed KRAS gene mutations in 5 subjects [25]. The KRAS gene encodes for K-Ras protein, a GTPase that converts GTP to GDP, which transmits signals downstream and leads to activation of ERK. The KRAS gene mutation leads to a gain in function of the K-Ras protein causing it to be permanently active. During embryonic development, the overactive K-Ras protein and ERK disrupt the growth and maturation of normal tissue leading to signs and symptoms of NS.

More recently, Roberts et al. [26] and Tartaglia et al. $[27,28]$ reported an SOS1 gene mutation located on chromosome 2 p22.1 which was present in $20 \%$ of NS cases. The SOS1 gene encodes for Ras-specific guanine nucleotide exchange factor (RAS-GEF) which is an important component in the receptor tyrosine kinase-mediated RAS-ERK cascade activation. A diagram of identified genes in NS and their proposed interaction with the GHIGF-I axis is shown in figure 1.

Mutations in two further genes have been reported in association with NS. The first of these is NF1 [29]. Heterozygous mutations of NF1 were reported in all of $7 \mathrm{pa}-$ tients who had some of the combined features of NS and neurofibromatosis type-1 (NF1) [30]. None of the patients had PTPN-11 mutations. It has been suggested that most variable phenotypes of the NF1-NS spectrum are variants of NF1. The fifth gene is RAF1, a downstream effector of RAS signaling in the MAPKinase pathway. Missense RAF1 mutations were reported in 18/231 individuals with NS and 2/6 patients with Leopard syndrome and were closely linked to hypertrophic cardiomyopathy [31]. Gain of function RAF1 mutations have been proposed as causative for NS and represent a new mechanism for the activation of the MAPKinase pathway [32].

To summarize, mutations in five known genes have been demonstrated in NS patients. PTPN11, KRAS, SOS1, NF1 and RAF1, accounting for $60-80 \%$ of cases. How

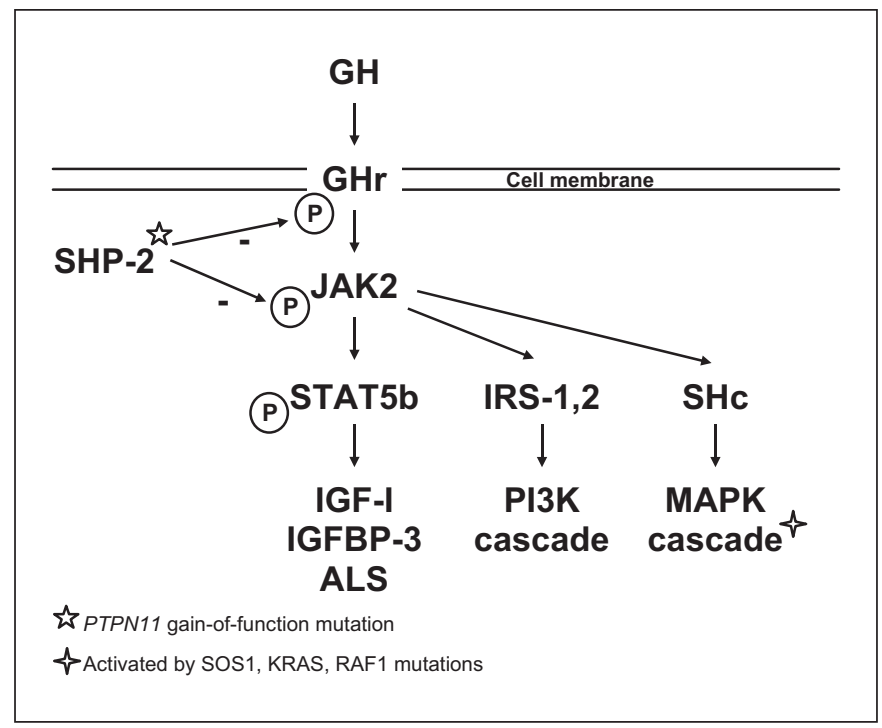

Fig. 1. Interaction between genes identified in Noonan syndrome and the pathways of $\mathrm{GH}$ action.

these mutations cause phenotypic changes is still unclear. However it must be remembered by the clinician that it is still possible to diagnose NS clinically in the absence of positive genetic findings.

\section{Genotype and Phenotype Relationships}

The causative influences of genetic mutations on the NS phenotype are not currently known. Numerous studies have tried to correlate the presence of genetic mutations with observed phenotypes. Mutations in PTPN11 lead to gain in function of SHP-2 which affects the morphogenesis of the semilunar valve in mice and may be responsible for pulmonary stenosis observed in some NS patients. Tartaglia et al. [23] studied 119 subjects of whom 54 were positive for PTPN11 mutations and found a significantly increased incidence of pulmonary stenosis in the PTPN11-positive (70.6\%) compared to mutation-negative (46.2\%) subjects. Hypertrophic cardiomyopathy was also more common in PTPN11 mutation-negative subjects and has now also been reported to have a strong association with RAF1 mutations [31, 32]. The NF1 gene mutations occur in patients with the overlap of NS and NF1 phenotypes [30].

Several studies have attempted to correlate genotype with parameters of linear growth. Birth weight and length were reported to be similar in PTPN11-positive $(\mathrm{n}=18)$ 
Table 2. Studies of GH therapy in Noonan syndrome

\begin{tabular}{|c|c|c|c|c|c|c|c|c|}
\hline & $\begin{array}{l}\text { Patients } \\
\mathrm{n}, \text { sex }\end{array}$ & $\begin{array}{l}\text { Study } \\
\text { duration } \\
\text { years }\end{array}$ & $\begin{array}{l}\text { Age at } \\
\text { start of } \\
\text { GH, years }\end{array}$ & GH dose & pretreatment & 1 year & 2 years & 3 years \\
\hline \multirow[t]{2}{*}{ Osio et al. [51] } & 11 , female & $2-10$ & $7.7 \pm 2.2$ & $\begin{array}{l}33(\mathrm{n}=6) \text { and } \\
66(\mathrm{n}=7) \mu \mathrm{g} / \mathrm{kg} / \text { day }\end{array}$ & $-3.1 \pm 0.5$ & ND & ND & ND \\
\hline & 7, male & $2-10$ & $8.6 \pm 3.4$ & $\begin{array}{l}33(\mathrm{n}=4) \text { and } \\
66(\mathrm{n}=8) \mu \mathrm{g} / \mathrm{kg} / \text { day }\end{array}$ & $-2.7 \pm 0.4$ & ND & ND & ND \\
\hline Macfarlane et al. [50] & 23 & 3 & $9.3 \pm 2.6$ & $0.33 \mathrm{mg} / \mathrm{kg} /$ week & $-2.7 \pm 0.4$ & $-2.2 \pm 0.6$ & $-2.1 \pm 0.9$ & $-1.9 \pm 0.9$ \\
\hline Cotterill et al. [41] & 27 & 1 & $8.9 \pm 0.5$ & $0.33 \mathrm{mg} / \mathrm{kg} /$ week & $-3.0 \pm 0.1$ & $-2.4 \pm 0.1$ & NA & NA \\
\hline Kirk et al. [46] & 66 & $1-6$ & $10.2 \pm 3.3$ & $0.8 \pm 0.24 \mathrm{U} / \mathrm{kg} /$ week & $-2.9 \pm 0.7$ & $-2.6 \pm 0.8$ & ND & ND \\
\hline Shaw et al. [14] & 10 & 12 & ND & $\mathrm{ND}$ & -3.4 & ND & ND & ND \\
\hline Noordam et al. [52] & GroupA, $\mathrm{n}=7$ & 4 & $9.5 \pm 2.9$ & $0.15 \mathrm{U} / \mathrm{kg} /$ day & $-3.2 \pm 0.8$ & ND & ND & $\mathrm{ND}$ \\
\hline
\end{tabular}

$\mathrm{NA}=$ Not applicable; $\mathrm{ND}=$ not described; $\mathrm{BA}=$ bone age, $\mathrm{HA}=$ Height age.

Noordham Study; Group A- GH for 2 years, discontinued for 3rd year, reinstituted for 4th year; Group B 1st year served as controls, GH administered for 2nd, 3rd \& 4th year; Group C GH administered for the first three years, 4th year served as control.

and negative subjects $(n=27)[12]$. A recent French study evaluated 35 individuals with NS of whom 20 were positive for the PTPN11 mutation [11]. There was a trend of decreased birth length in mutated $(-1.4 \pm 1.2 \mathrm{SD})$ compared with non-mutated $(-0.9 \pm 1.0 \mathrm{SD})$ newborns but the difference was not significant $(\mathrm{p}=0.24)$, although 6 mutated and 2 non-mutated subjects were small for gestational age.

Studies of postnatal growth provide conflicting data on the severity of short stature between mutation-positive and mutation-negative groups. Kosaki et al. [33] reported severe growth restriction in 6 of 7 PTPN11-positive cases. Growth in a study of 45 subjects was comparable in mutation-positive and mutation-negative males, whereas height SDS was lower in mutation-positive females [12]. In other studies, there were no differences in growth parameters between 51 mutation-positive and 64 mutation-negative subjects [23] nor in the analysis of growth to final height in 56 cases by Shaw et al. [14]. However, in other studies of NS, patients with PTPN11 mutations were significantly shorter than those without the mutation [34, 35]. Zenker et al. [34] reported that $82 \%$ of 34 mutation-positive cases had heights less than -2 (mean -3.1) SDS compared with $57 \%$ of the 23 mutation-negative subjects (mean -2.4 SDS). Similarly, Sarkozy et al. [35] found that $86 \%$ of mutation-positive cases compared with $40 \%$ of mutation-negative cases had short stature.
Limal et al. [11] also reported more pronounced growth disturbance in mutation-positive subjects at the age of 6 years. To date only one study has described the phenotype in cases with KRAS germline mutations, which showed that 8 such patients had heights below the 10th centile [36].

\section{Growth Hormone-IGF-I Axis}

Qualitatively abnormal spontaneous GH secretion with high trough GH levels consistent with neurosecretory dysfunction has been reported [37-39]. In a large study of 150 NS subjects from the National Cooperative Growth Study (NCGS), Romano et al. [40] reported that $45 \%$ had peak GH responses to provocation with $<10$ $\mu \mathrm{g} / \mathrm{l}$. Cotterill et al. [41] reported similar data with 10 of 27 children having peak GH levels of $<12.5 \mu \mathrm{g} / \mathrm{l}$. Other studies have reported normal GH secretion [11, 42]. Several investigators have reported low IGF-I levels [11, 4143], whereas IGFBP-3 is usually normal [11, 41]; amyotrophic lateral sclerosis may be decreased.

There are theoretical reasons why PTPN11, RAS, SOS1 and RAF1 mutations may affect the function of the GH axis, leading to some deficiency of IGF-I (fig. 1). GH secretion and GH-dependent peptides have been compared in PTPN11 mutation-positive and mutation-negative 


\begin{tabular}{|c|c|c|c|c|c|c|c|c|}
\hline $\begin{array}{l}\Delta \text { Height SDS } \\
\text { after treatment }\end{array}$ & $\begin{array}{l}\text { Final height } \\
\text { SDS }\end{array}$ & \multicolumn{4}{|c|}{ Height velocity, $\mathrm{cm} /$ years } & \multicolumn{2}{|l|}{ Bone age } & $\Delta \mathrm{BA} / \Delta \mathrm{HA}$ \\
\hline $1.5 \pm 0.8$ & $-1.6 \pm 0.8$ & ND & ND & ND & ND & ND & ND & ND \\
\hline $1.8 \pm 1.0$ & $-0.9 \pm 1.2$ & ND & ND & ND & ND & ND & ND & ND \\
\hline $\mathrm{ND}$ & ND & $4.4 \pm 1.7$ & $8.4 \pm 1.7$ & $6.2 \pm 1.7$ & $5.8 \pm 1.8$ & ND & ND & ND \\
\hline $0.65 \pm 0.1$ & NA & $4.9 \pm 0.2$ & $8.1 \pm 0.4$ & NA & NA & $7.6 \pm 0.4$ & $9.3 \pm 0.5$ & ND \\
\hline ND & ND & $4.8 \pm 1.1$ & $7.2 \pm 1.7$ & $\mathrm{ND}$ & ND & ND & $\mathrm{ND}$ & 1.0 \\
\hline ND & -2.7 & ND & ND & ND & ND & ND & ND & ND \\
\hline $0.8 \pm 0.7$ & ND & ND & $\mathrm{ND}$ & $\mathrm{ND}$ & ND & $7.8 \pm 2.8$ & ND & $1.1 \pm 0.1$ \\
\hline
\end{tabular}

subjects [11, 42]. Binder et al. [43] reported spontaneous and stimulated GH secretion to be significantly higher and IGF-I levels significantly lower in mutation-positive subjects suggesting mild GH resistance. Since tyrosine phosphorylation is a critical component of GH receptor signaling, it is thought that the abnormally enhanced phosphatase activity of SHP-2 leads to increased tyrosine dephosphorylation and may disturb GH receptor and JAK2 interaction thus interrupting GH-stimulated pathways $[44,45]$.

\section{Growth Hormone Therapy}

The efficacy of GH therapy in other non-GH-deficient disorders such as Turner syndrome, together with the demonstration of possible GH-IGF1 axis abnormalities has led to research into the use of GH in NS. Most reports are of observational studies involving small numbers of subjects and lacking randomization or control groups. The dosage used has varied from standard replacement doses to higher doses such as those used in Turner syndrome (table 2). Most studies have reported fair shortterm responses to $\mathrm{GH}$ therapy by demonstrating an increase in height velocity [37, 40,41,46-48]. Short-term growth acceleration comparable to that seen in Turner syndrome has been reported $[40,49]$. However over a pe- riod of time waning of the response has been reported $[44,48,50]$. Some longer-term studies have reported no sustained catch-up growth, although height gain was maintained until the onset of puberty [51]. An acceleration in bone maturation has been demonstrated which could compromise the GH response to adult height [52]. In May 2007, NovoNordisk obtained FDA approval for treatment of NS with their GH preparation norditropin using a dose of $0.066 \mathrm{mg} / \mathrm{kg} / \mathrm{day}$.

\section{Adult Height}

Only a small number of studies have reported adult heights achieved with prolonged GH treatment. Kirk et al. [46] reported a disappointing gain in adult height of $+0.8 \mathrm{SDS}(3 \mathrm{~cm})$ after a mean of 5.3 years treatment in 10 patients. Only 1 child reached final height above the $3 \mathrm{rd}$ centile.

An uncontrolled study of 18 children who reached adult height after a mean duration of treatment of 7.5 years reported an increase in height SDS from $-2.9 \pm 0.4$ before GH therapy to $-1.2 \pm 1.0$. This was equivalent to a gain of $10.3 \mathrm{~cm}$ compared to pretreatment predicted adult height [51]. The initial rhGH dose in this study was either 0.033 or $0.066 \mathrm{mg} / \mathrm{kg} /$ day. FDA approval has recently been given to rhGH treatment of short children with NS in the US, using doses up to $0.066 \mathrm{mg} / \mathrm{kg}$ day. 
Table 3. Response to growth hormone treatment in Noonan syndrome patients with and without PTPN11 mutations

\begin{tabular}{|c|c|c|c|c|c|}
\hline Reference & Parameter & $\begin{array}{l}\text { Number of patients } \\
\text { (mut }+/ \text { mut }- \text { ) }\end{array}$ & PTPN11 mutation+ & PTPN11 mutation- & $\mathrm{p}$ value \\
\hline \multicolumn{6}{|l|}{ Height SDS } \\
\hline \multirow[t]{3}{*}{ Limal et al. 2006 [11] } & Pre-Tx Ht SDS & $15 / 10$ & $-3.5 \pm 0.9$ & $-3.0 \pm 0.8$ & 0.18 \\
\hline & Year $1 \mathrm{Ht}$ SDS & $15 / 10$ & $-3.1 \pm 1.2$ & $-2.4 \pm 0.7$ & 0.08 \\
\hline & Year 2 Ht SDS & $15 / 10$ & $-3.1 \pm 1.4$ & $-2.0 \pm 0.9$ & 0.03 \\
\hline \multirow[t]{2}{*}{ Binder et al. 2005 [43] } & Pre-Tx Ht SDS & $8 / 3$ & $-3.46 \pm 0.71$ & $-3.80 \pm 0.13$ & 0.44 \\
\hline & Year $1 \Delta$ Ht SDS & $8 / 3$ & $+0.66 \pm 0.21$ & $+1.26 \pm 0.36$ & 0.007 \\
\hline \multirow[t]{4}{*}{ Ferreira et al. 2005 [42] } & Pre-Tx Ht SDS & $7 / 7$ & $-3.6 \pm 1$ & $-3.4 \pm 1$ & NS \\
\hline & Year $1 \Delta$ Ht SDS & $7 / 7$ & $+0.30 \pm 0.41$ & $+0.42 \pm 0.43$ & NS \\
\hline & Years $1-2 \Delta \mathrm{Ht}$ SDS & $6 / 6$ & $+0.69 \pm 0.45$ & $+0.82 \pm 0.70$ & NS \\
\hline & Years $1-3 \Delta \mathrm{Ht}$ SDS & $4 / 4$ & $+0.76 \pm 0.41$ & $+1.74 \pm 0.10$ & $<0.01$ \\
\hline \multicolumn{6}{|l|}{ Height velocity, $\mathrm{cm} /$ years } \\
\hline \multirow[t]{3}{*}{ Limal et al. 2006 [11] } & Pre-Tx HV & $15 / 10$ & $4.3 \pm 0.9$ & $5.2 \pm 1.4$ & 0.09 \\
\hline & Year $1 \mathrm{HV}$ & $15 / 10$ & $7.4 \pm 1.6$ & $8.5 \pm 1.7$ & 0.09 \\
\hline & Year $2 \mathrm{HV}$ & $15 / 10$ & $5.8 \pm 1.4$ & $6.9 \pm 1.6$ & 0.13 \\
\hline \multirow[t]{4}{*}{ Ferreira et al. 2005 [42] } & Pre-Tx HV & $7 / 7$ & $4.3 \pm 1.0$ & $3.9 \pm 1.4$ & NS \\
\hline & Year $1 \mathrm{HV}$ & $7 / 7$ & $6.8 \pm 1.5$ & $7.6 \pm 1.9$ & NS \\
\hline & Year $2 \mathrm{HV}$ & $6 / 6$ & $5.4 \pm 1.5$ & $7.1 \pm 2.3$ & NS \\
\hline & Year $3 \mathrm{HV}$ & $4 / 5$ & $5.7 \pm 1.5$ & $7.0 \pm 3.8$ & NS \\
\hline
\end{tabular}

$\mathrm{HT}=$ Height; HV = height velocity; NS = not significant; $\mathrm{Tx}=\mathrm{GH}$ therapy.

Genetics and Response to Growth Hormone (table 3)

Results of GH therapy related to PTPN11 mutation status have been reported in three studies. Growth responses to GH were significantly greater in mutationnegative subjects, consistent with the hypothesis of $\mathrm{GH}$ resistance in the mutation-positive patients [11, 42, 43]. However the growth response to GH therapy is difficult to predict. We have recently seen an excellent response to GH therapy in a young NS child who had biochemical features of GH resistance but was negative for the PTPN11 mutation [53]. GH-dependent growth factors all normalized on GH treatment.

\section{Cardiac Status}

GH therapy in NS children with congenital heart diseases may pose potential risks of aggravation of the heart condition. Most of the studies have excluded subjects with hypertrophic cardiomyopathy. However no adverse effects on cardiac muscle mass has been reported and no patients have developed features of hypertrophic cardiomyopathy during treatment with GH $[41,54]$. Although GH therapy may be best avoided in children with active cardiac decompensation, in the child without detectable cardiac dysfunction GH treatment does not appear to be contraindicated.

\section{Possible Rationale for rhIGF-I Therapy}

The theoretical disturbance of the GH-IGF-I axis in NS, particularly that of impaired IGF-I production in mutation-positive patients, has been discussed above. There may be a rationale for a clinical trial of rhIGF-I therapy in patients with severely abnormal growth who have biochemical features of GH resistance. The indication for rhIGF-I therapy may be strengthened by a lack of response to GH therapy. As discussed previously, growth in NS is variable and the response to GH therapy is difficult to predict with confidence. Nonetheless, we feel that in the NS patient with severe growth failure, some benefit can be expected with GH as first-line therapy. rhIGF-I may in the future be considered a second-line option, particularly for mutation-positive patients, however no data have been reported to support a recommendation at this time.

\section{Conclusions}

NS is a phenotypically heterogeneous clinical disorder characterized by certain recognizable physical abnormalities. In childhood, impaired linear growth is one of 
the more concerning features of NS, which may be accompanied by pubertal delay. Genetic defects have been demonstrated which may affect the function of the GHIGF-I axis, and have been reported to affect over $60 \%$ of cases. However, there are likely other, as yet unidentified, genetic defects causing the NS phenotype, since classical familial NS can occur in the absence of the known mutations.

The growth pattern in NS is variable and approximately half of the affected individuals attain adult heights below the normal range without treatment. The response to rhGH therapy has likewise been variable, with modest increases in height velocity on standard doses. The PTPN11 mutation appears to be a pharmacogenetic predictor of GH responsiveness. rhGH therapy using higher doses similar to those licensed for Turner syndrome have been shown to give substantial short-term increases in height velocity. Longer-term benefit has been reported in a small number of patients treated to adult height. Marketing approval has been granted in the US, but not currently in Europe. Due to the possibility of impaired IGFI generation in NS, treatment with rhIGF-I should be explored in future studies.

\section{References}

$\checkmark 1$ Ullrich O: Ueber typische Kombinationsbilder multipler Abarten. Z Kinderheilk 1930;49:271-276.

-2 Noonan JA: Hypertelorism with Turner phenotype. A new syndrome with associated congenital heart disease. Am J Dis Child 1968;116:373-380.

- 3 Witt DR, Keena BA, Hall JG, Allanson JE: Growth curves for height in Noonan syndrome. Clin Genet 1986;30:150-153.

4 Allanson JE, Hall JG, Hughes HE, Preus M, Witt DR: Noonan syndrome: the changing phenotype. Am J Med Genet 1985;21:507514.

5 Sharland M, Burch M, McKenna WM, Patton MA: A clinical study of Noonan syndrome. Arch Dis Child 1992;67:178-183.

6 Duncan WJ, Fowler RS, Farkas LG, Ross RB, Wright AW, Bloom KR, Huot DJ, Sondheimer HM, Rowe RD: A comprehensive scoring system for evaluating Noonan syndrome. Am J Med Genet 1981;10:37-50.

7 van der Burgt I, Berends E, Lommen E, van BS, Hamel B, Mariman E: Clinical and molecular studies in a large Dutch family with Noonan syndrome. Am J Med Genet 1994; 53:187-191.

-8 Jongmans M, Sistermans EA, Rikken A, Nillesen WM, Tamminga R, Patton M, Maier EM, Tartaglia M, Noordam K, van der Burgt I: Genotypic and phenotypic characterization of Noonan syndrome: new data and review of the literature. Am J Med Genet A 2005;134:165-170.

-9 Ranke MB, Heidemann P, Knupfer C, Enders H, Schmaltz AA, Bierich JR: Noonan syndrome: growth and clinical manifestations in 144 cases. Eur J Pediatr 1988;148:220227.

10 Allanson JE: Noonan syndrome. J Med Genet 1987;24:9-13.
Limal JM, Parfait B, Cabrol S, Bonnet D, Leheup B, Lyonnet S, Vidaud M, Le BY: Noonan syndrome: relationships between genotype, growth, and growth factors. J Clin Endocrinol Metab 2006;91:300-306.

12 Yoshida R, Hasegawa T, Hasegawa Y, Nagai T, Kinoshita E, Tanaka Y, Kanegane $\mathrm{H}$, Ohyama K, Onishi T, Hanew K, Okuyama T, Horikawa R, Tanaka T, Ogata T: Protein-tyrosine phosphatase, nonreceptor type 11 mutation analysis and clinical assessment in 45 patients with Noonan syndrome. J Clin Endocrinol Metab 2004;89:3359-3364.

13 Noonan JA, Raaijmakers R, Hall BD: Adult height in Noonan syndrome. Am J Med Genet 2003;123:68-71.

14 Shaw AC, Kalidas K, Crosby AH, Jeffery S, Patton MA: The natural history of Noonan syndrome: a long-term follow-up study. Arch Dis Child 2007;92:128-132.

15 Mendez HM, Opitz JM: Noonan syndrome: a review. Am J Med Genet 1985;21:493-506.

16 Jongmans M, Otten B, Noordam K, van der Burgt I: Genetics and variation in phenotype in Noonan syndrome. Horm Res 2004; 62(suppl 3):56-59.

17 van der Burgt I, Brunner H: Genetic heterogeneity in Noonan syndrome: evidence for an autosomal recessive form. Am J Med Genet 2000;94:46-51.

-18 Jamieson CR, van der Burgt I, Brady AF, Van Reen M, Elsawi MM, Hol F, Jeffery S, Patton MA, Mariman E: Mapping a gene for Noonan syndrome to the long arm of chromosome 12. Nat Genet 1994;8:357-360.

19 Brady AF, Jamieson CR, van der Burgt I, Crosby A, Van Reen M, Kremer H, Mariman E, Patton MA, Jeffery S: Further delineation of the critical region for Noonan syndrome on the long arm of chromosome 12. Eur J Hum Genet 1997;5:336-337.
20 Legius E, Schollen E, Matthijs G, Fryns JP: Fine mapping of Noonan/cardio-facio cutaneous syndrome in a large family. Eur J Hum Genet 1998;6:32-37.

21 Chen B, Bronson RT, Klaman LD, Hampton TG, Wang JF, Green PT, Magnuson T, Douglas PS, Morgan JP, Neel BG: Mice mutant for Egfr and Shp2 have defective cardiac semilunar valvulogenesis. Nat Genet 2000;24:296299

22 Tartaglia M, Mehler EL, Goldberg R, Zampino G, Brunner HG, Kremer H, van der Burgt I, Crosby AH, Ion A, Jeffery S, Kalidas K, Patton MA, Kucherlapati RS, Gelb BD: Mutations in PTPN11, encoding the protein tyrosine phosphatase SHP-2, cause Noonan syndrome. Nat Genet 2001;29:465-468.

23 Tartaglia M, Kalidas K, Shaw A, Song X, Musat DL, van der Burgt I, Brunner HG, Bertola DR, Crosby A, Ion A, Kucherlapati RS, Jeffery S, Patton MA, Gelb BD: PTPN11 mutations in Noonan syndrome: molecular spectrum, genotype-phenotype correlation, and phenotypic heterogeneity. Am J Hum Genet 2002;70:1555-1563.

24 Tartaglia M, Gelb BD: Noonan syndrome and related disorders: genetics and pathogenesis. Annu Rev Genomics Hum Genet 2005;6:45-68.

25 Schubbert S, Zenker M, Rowe SL, Boll S, Klein C, Bollag G, van der Burgt I, Musante L, Kalscheuer V, Wehner LE, Nguyen $H$, West B, Zhang KY, Sistermans E, Rauch A, Niemeyer CM, Shannon K, Kratz CP: Germline KRAS mutations cause Noonan syndrome. Nat Genet 2006;38:331-336.

26 Roberts AE, Araki T, Swanson KD, Montgomery KT, Schiripo TA, Joshi VA, Li L, Yassin Y, Tamburino AM, Neel BG, Kucherlapati RS: Germline gain-of-function mutations in SOS1 cause Noonan syndrome. Nat Genet 2007;39:70-74. 
-27 Tartaglia M, Pennacchio LA, Zhao C, Yadav KK, Fodale V, Sarkozy A, Pandit B, Oishi K, Martinelli S, Schackwitz W, Ustaszewska A, Martin J, Bristow J, Carta C, Lepri F, Neri C, Vasta I, Gibson K, Curry CJ, Siguero JP, Digilio MC, Zampino G, Dallapiccola B, BarSagi D, Gelb BD: Gain-of-function SOS1 mutations cause a distinctive form of Noonan syndrome. Nat Genet 2007;39:75-79.

-28 Tartaglia M, Pennacchio LA, Zhao C, Yadav KK, Fodale V, Sarkozy A, Pandit B, Oishi K, Martinelli S, Schackwitz W, Ustaszewska A, Martin J, Bristow J, Carta C, Lepri F, Neri C, Vasta I, Gibson K, Curry CJ, Siguero JP, Digilio MC, Zampino G, Dallapiccola B, BarSagi D, Gelb BD: Corrigendum: Gain-offunction SOS1 mutations cause a distinctive form of Noonan syndrome. Nat Genet 2007; 39:276.

-29 Noordam K: Expanding the genetic spectrum of Noonan syndrome. Horm Res 2007; 68:24-27

>30 Hüffmeier U, Zenker M, Hoyer J, Fahsold R, Rauch A: A variable combination of features of Noonan syndrome and neurofibromatosis type 1 are caused by mutations of the NF1 gene. Am J Med Genet A 2006;140:27492756.

-31 Pandit B, Sarkozy A, Pennacchio LA, Carta C, Oishi K, Martinelli S, Pogna EA, Schackwitz W, Ustaszewska A, Landstrom A, Bos JM, Ommen SR, Esposito G, Lepri F, Faul C, Mundel P, Lopez Siguero JP, Tenconi R, Selicorni A, Rossi C, Mazzanti L, Torrente I, Marino B, Digilio MC, Zampino G, Ackerman MJ, Dallapiccola B, Tartaglia M, Gelb BD: Gain-of-function RAF1 mutations cause Noonan and leopard syndromes with hypertrophic cardiomyopathy. Nat Genet 2007;39: 1007-1012.

\32 Razzaque MA, Nishizawa T, Komoike Y, Yagi H, Furutani M, Amo R, Kamisago M, Momma K, Katayama H, Nagakawa M, Fugiwara Y,Matsushima M,Mizuno K, Tokuyama M, Hiroto H, Muneuchi J, Higashinakagawa T, Matsuoka R: Germline gain-of-function mutations in RAF1 cause Noonan syndrome. Nat Genet 2007;39:1013-1017.

33 Kosaki K, Suzuki T, Muroya K, Hasegawa T, Sato S, Matsuo N, Kosaki R, Nagai T, Hasegawa Y, Ogata T: PTPN11 (protein-tyrosine phosphatase, nonreceptor-type 11) mutations in seven Japanese patients with Noonan syndrome. J Clin Endocrinol Metab 2002; 87:3529-3533.

-34 Zenker M, Buheitel G, Rauch R, Koenig R, Bosse K, Kress W, Tietze HU, Doerr HG, Hofbeck M, Singer H, Reis A, Rauch A: Genotype-phenotype correlations in Noonan syndrome. J Pediatr 2004;144:368-374.
35 Sarkozy A, Conti E, Seripa D, Digilio MC, Grifone N, Tandoi C, Fazio VM, Di C, V, Marino $\mathrm{B}$, Pizzuti A, Dallapiccola B: Correlation between PTPN11 gene mutations and congenital heart defects in Noonan and LEOPARD syndromes. J Med Genet 2003;40:704708.

36 Zenker M, Lehmann K, Schulz AL, Barth H, Hansmann D, Koenig R, Korinthenberg R, Kreiss-Nachtsheim M, Meinecke P, Morlot S, Mundlos S, Quante AS, Raskin S, Schnabel D, Wehner LE, Kratz CP, Horn D, Kutsche K: Expansion of the genotypic and phenotypic spectrum in patients with KRAS germline mutations. J Med Genet 2007;44:131-135.

-37 Ahmed ML, Foot AB, Edge JA, Lamkin VA, Savage MO, Dunger DB: Noonan's syndrome: abnormalities of the growth hormone/IGF-I axis and the response to treatment with human biosynthetic growth hormone. Acta Paediatr Scand 1991;80:446450.

38 Noordam C, van der Burgt I, Sweep CG, Delemarre-van de Waal HA, Sengers RC, Otten BJ: Growth hormone $(\mathrm{GH})$ secretion in children with Noonan syndrome: frequently abnormal without consequences for growth or response to $\mathrm{GH}$ treatment. Clin Endocrinol (Oxf) 2001;54:53-59.

39 Tanaka K, Sato A, Naito T, Kuramochi K, Itabashi H, Takemura Y: Noonan syndrome presenting growth hormone neurosecretory dysfunction. Intern Med 1992;31:908-911.

40 Romano AA, Blethen SL, Dana K, Noto RA: Growth hormone treatment in Noonan syndrome: the National Cooperative Growth Study experience. J Pediatr 1996;128:S18S21.

41 Cotterill AM, McKenna WJ, Brady AF, Sharland M, Elsawi M, Yamada M, CamachoHubner C, Kelnar CJ, Dunger DB, Patton MA, Savage MO: The short-term effects of growth hormone therapy on height velocity and cardiac ventricular wall thickness in children with Noonan's syndrome. J Clin Endocrinol Metab 1996;81:2291-2297.

42 Ferreira LV, Souza SA, Arnhold IJ, Mendonca BB, Jorge AA: PTPN11 (protein tyrosine phosphatase, nonreceptor type 11) muta tions and response to growth hormone therapy in children with Noonan syndrome. J Clin Endocrinol Metab 2005;90:5156-5160.

43 Binder G, Neuer K, Ranke MB, Wittekindt NE: PTPN11 mutations are associated with mild growth hormone resistance in individuals with Noonan syndrome. J Clin Endocrinol Metab 2005;90:5377-5381.

-44 Stofega MR, Herrington J, Billestrup N, Carter-Su C: Mutation of the SHP-2 binding site in growth hormone $(\mathrm{GH})$ receptor prolongs GH-promoted tyrosyl phosphorylation of GH receptor, JAK2, and STAT5B. Mol Endocrinol 2000;14:1338-1350.
45 Maile LA, Clemmons DR: Regulation of insulin-like growth factor 1 receptor dephosphorylation by SHPS-1 and the tyrosine phosphatase SHP-2. J Biol Chem 2002;277: 8955-8960.

$\checkmark 46$ Kirk JM, Betts PR, Butler GE, Donaldson MD, Dunger DB, Johnston DI, Kelnar CJ, Price DA, Wilton P, Group tU: Short stature in Noonan syndrome: response to growth hormone therapy. Arch Dis Child 2001;84: 440-443.

47 De Schepper J, Otten BJ, Francois I, Bourguignon JP, Craen M, van der Burgt, I, Massa GG: Growth hormone therapy in pre-pubertal children with Noonan syndrome: first year growth response and comparison with Turner syndrome. Acta Paediatr 1997;86: 943-946.

48 Ogawa M, Moriya N, Ikeda H, Tanae A, Tanaka T, Ohyama K, Mori O, Yazawa T, Fujita K, Seino Y, Kubo T, Tanaka H, Nishi Y, Yoshimoto M: Clinical evaluation of recombinant human growth hormone in Noonan syndrome. Endocr J 2004;51:61-68.

49 De Schepper J, Otten BJ, Francois I, Bourguignon JP, Craen M, Van der Burgt I, Massa GG: Growth hormone therapy in pre-pubertal children with Noonan syndrome: first year growth response and comparison with Turner syndrome. Acta Paediatr 1997;86: 943-946.

50 Macfarlane CE, Brown DC, Johnston LB, Patton MA, Dunger DB, Savage MO, McKenna WJ, Kelnar CJH: Growth hormone therapy and growth in children with Noonan's syndrome: results of 3 years' follow-up. J Clin Endocrinol Metab 2001;86:19531956

51 Osio D, Dahlgren J, Wikland KA, Westphal O: Improved final height with long-term growth hormone treatment in Noonan syndrome. Acta Paediatr 2005;94:1232-1237.

52 Noordam C, van der Burgt I, Sengers RC, Delemarre-van de Waal HA, Otten BJ: Growth hormone treatment in children with Noonan's syndrome: four year results of a partly controlled trial. Acta Paediatr 2001; 90:889-894.

53 Walton-Betancourth S, Martinelli CE, Thalange NKS, Dyke MP, Acerini CL, White S, Camacho-Hübner C, Savage MO: Excellent growth response to grow th hormone therapy in a child with PTPN11-negative Noonan syndrome. J Endocrinol Invest 2007;30:439441.

54 Noordam C, Draaisma JM, van den Nieuwenhof J, van der Burgt I, Otten BJ, Daniels O: Effects of growth hormone treatment on left ventricular dimensions in children with Noonan's syndrome. Horm Res 2001;56: 110-113. 